\title{
Sikap dan Kepatuhan Minum Suplemen Zat Besi Berhubungan dengan Kadar Hemoglobin Pada Remaja Putri
}

\author{
Tuti Rohani ${ }^{1 *}$, Fiya Diniarti ${ }^{2 *}$, Tita Restu Yuliasri ${ }^{3 *}$ \\ 1, 2 Universitas Dehasen, Bengkulu, Indonesia \\ 3 Politeknik Kesehatan Ummi Khasanah, Yogyakarta, Indonesia \\ *rohani.tuti@yahoo.com
}

\section{ARTICLE INFO}

\section{Article history:}

Received January 29,2022

Accepted January 29, 2022

Published January 30, 2022

\section{Kata Kunci:}

Sikap

Perilaku Kepatuhan

Suplemen Zat Besi dan Kadar

Hemoglobin

Key words:

Attitude

Compliance Behaviour

Iron Supplementation and

Haemoglobin Levels

\section{DOI:}

https://10.48092/jik.v8i1.165

\section{ABSTRAK}

Latar Belakang: Prevalensi anemia terus meningkat pada usia reproduktif peningkatan terjadi setiap tahunya $29,4 \%$ sampai $33,3 \%$, penyebab terbanyak dari anemia adalah kekurangan zat besi. Pelitian ini bertujuan untuk mengetahi hubungan Sikap dan perilaku kepatuhan minum suplemen zat besi pada remaja putri sekolah dengan kadar hemoglobin. Metode: Penelitian ini dengan pendekatan Cross Sectional, dilakukan di Kabupaten Bantul, Yogyakarta, Indoneisa. Jumlah responden 239 remaja putri sekolah berusia 15 sampai 18 tahun. Hasil: Didaptkan hasil 49,6 \% remaja putri mengalami anemia. Factorfaktor yang berhubungan dnegan anemia adalah sikap ( $p$ value $=0.014)$, perilaku minum zat besi ( $p$ value $=0.001)$, setelah dilakukan uji multivariat kepatuhan minum zat besi menjadi faktor dominan dengan OR 3,5. Kesimpulan: Dapat disimpulkan bahwa dengan sikap yang mendukung dan mengkonsumsi suplemen zat besi secara teratur dapat meningkatkan kadar hemogolobin pada remja putri sekolah.

\section{ABSTRACT \\ Attitude and Compliance with Taking Iron Supplements Are Associated with Haemoglobin Levels in Adolescent Girls}

Background: The prevalence of anemia continues to increase at reproductive age, the increase occurs every year from $29.4 \%$ to $33.3 \%$, the most common cause of anemia is iron deficiency. This study aims to determine the relationship between attitudes and behavior of adherence to taking iron supplements in schoolgirls with hemoglobin levels. Methods: This study used a Croos Sectional approach. Early research was conducted in Bantul district, Yogyakarta province, Indonesia. The number of respondents was 239 schoolgirls aged 15 to 18 years. Results: it was found that 49.6\% of adolescent girls were anemic. Factors related to anemia were attitude ( $p$ value $=0.014)$, behavior of drinking iron ( $p$ value $=0.001)$, after multivariate test, adherence to iron intake became the dominant factor with an OR of 3.5. Conclusion: It can be concluded that a supportive attitude and taking iron supplements regularly can increase the hemoglobin levels in adolescent school girls.

Thisopenaccessarticleisunderthe $C C-B Y$-SAlicense. 


\section{PENDAHULUAN}

Target pengurangan kejadian anemia sebesar 50 $\%$ pada wanita usia reproduktif secara global pada tahun 2025, anemia merupakan konsentrasi jumlah dan ukuran sel darah merah berada pada kondisi di bawah normal, sehingga berakibat pada gizi dan kesehatan yang buruk dan gangguan pengangkutan oksigen karena kapasiatas darah yang berkurang (Global and Targets, 2012). Prevalensi anemia terus meningkat pada usia reproduktif yang tidak hamil, peningkatan terjadi setiap tahunya 29,4\% sampai 33,3\% sehingga berakibat meningktnya anemia pada populasi global. Anemia pada wanita usia reproduktif yang tidak hamil akan mengakibatkan masalah kesehatan, prevalensi teritinggi terjadi diwilayah afrika, asia tenggara dan mediterania timur(Learnt et al., 2018), anemia terjadi pada usia 1215 tahun, di Wilayah Asia Tenggara lebih dari 25\% anak perempuan remaja menderita anemia kecuali Thailand dan mencapai $50 \%$ di beberapa negara lainya.(World Health Organization, 2011).

Penyebab aneima sangat komplek dari berbagai faktor yaitu kekurangan gizi dan zat besi (Gebreyesus et al., 2019), pertumbuhan, jenis kelamin, peradangan dan infeksi (malaria, infeksi cacing, HIV, tuberkulosis ), kelainan hemoglobin serta faktor perilaku, sosial dan lingkungan(WHO, 2017), anemia beresiko tinggai terjadi remaja putri di usia dini dan mereka yang tinggal di rumah tangga rawan pangan (Gebreyesus et al., 2019). Remaja putri sekolah rentan terkena anemia karena faktor kurangnya keragaman makanan(Azupogo et al., 2019), status sosial ekonomi rendah dan lama menstruasi sehingga anmeia dapat dicegah dengan konsumsi pangan yang beragam dan kaya zat besi (Fentie, Wakayo and Gizaw, 2020). Berdasarkan beberapa penelitian dan teori Remaja putri merupakan kelompok yang rentan ternjadinya anemia yang disebabkan karena kekurangan zat besi yang disebabkan oleh kekurangan mikronutrien pada komsumsi makan sehari-hari dan reaja putri berada pada masa pertumbuhan.

Anemia pada remaja putri meurpakan permasalahan yang harus segera diatasi kareana akan berakibat terhadap kesehatan reproduksi pada remaja putri. Anemia pada remaja putri akan berdampak langsung pada saat ini dan tidak langsung pada masa depannya. Anemia pada remaja berakibat menurunkan konsentrasi dan produktivitas kerja, dapat mengganggu pertumbuhan dimana tinggi dan berat badan menjadi tidak sempurna, menurunkan daya tahan tubuh sehingga mudah terserang penyakit (Azupogo et al., 2019). Berdasarkan beberapa penelitian anemia pada ibu berakibat saat kehamilan dan persalinan, dapat terjadinya abortus dan melahirkan bayi dengan berat badan lahir rendah (Ghislain K. Koura et al., 2012)dan akan terjadi penuruan kadar hemoglobin pada bayi (Ghislain K Koura et al., 2012), mengalami penyulit saat melahirkan bayi rendahnya Apgar Score (Alizadeh et al., 2014). Dampak anemia tidak pada remaja saja namum akan memberi dampak pada generasi yang akan datang.

Berdasarkan World Health Assembly (WHA) global nutrition target 2025 yaitu pengurangan $50 \%$ anemia pada wanita usia reproduktif, diperlukan pendekatan multi faktor dan multi sektoral untuk mencapai target (Sataloff, Johns and Kost, no date). Fokus intervensi pada penecgahan dan pengobatan lebih awal akan menujukan hasil yang baik(Habib, Abbasi and Aziz, 2020) Anemia yang disebabkan karena nutrisi dapat dilakukan solusi dengan memberikan suplementasi, keanekaragaman pangan dan fortifikasi makanan (Organization, 2017) Pemberian Weekly IronFolic Acid Supplementation (WIFS) dapat mencegah dan menurukan prevalensi anemia zat besi (Global and Targets, 2012; Organization, 2017).

Berdasarkan beberapa penelitian, beberepa pendekatan telah dilakukan penelitian yang dilakukan Mengistu at all pada remaja putri sekolah di wilayah pedesaan Ethiopia dengan strategi intervensi pada pencegahan pendidikan gizi, skrining, dan program suplementasi zat besi serta pengobatan dini parasit usus (Mengistu, Azage and Gutema, 2019). Pemberian Weekly Iron-Folic Acid Supplementation (WIFS) untuk remaja putri bersama penanganan cacingan berhasil emnurunkan anemia pada remaja putri di Pholhong, provinsi Vientiane, Lao PDR. Permasalahn yang masih ditemukan dalah ditribusi suplemen pada perempuan yang tidak sekolah masih menjadi kendala. (Kounnavong et al., 2020).

Program Weekly Iron-Folic Acid Supplementation (WIFS) mengalami banyak hambatan seperti pada penelitian di Odhisa India bahwa masih adanya kepercayaan mengkonsumsi suplemen zat besi pada kehamilan membuat bayi menjadi besar yang akan berakibat pada kelahiran operasi caesar dengan biaya yang mahal. Petugas kesehatan tidak mendistribusikan suplemen zat besi pada wanita usia reproduktif hanya wanita hamil saja dan tidak memonitoring kepatuhan (Sedlander et al., 2020). Permasalahan kepatuhan terjadi karena komunitas tidak memahami program suplementasi zat besi dan ketidak patuhan remaja dikarenakan faktor budaya (Compaoré et al., 2018).

Kendala utama program WIFS adalah kepatuhan remaja minum suplemen zat besi telah dilakukan berbagai pendekatan yang telahdilakukan adalah pendidikan teman sebaya, peyuluhan yang dilakukan oleh petugas kesehatan, dan penyuluhan oleh guru pembmbing, namum belum memberikan hasil yang maksimal, dikarena jumlah petugas kesehatan yang minimal dibandingkan dengan jumlah remaja putri, penyuluhan hanya perwakilan saja dari beberapa remaja putri, hasil yang didapat tidak smeua remaja mendapat penyuluhan tentang anemia degan demikian program 
pencegahan anemia berjalan baik, terlihat masih tingginya ketidakpatuhan dan prevalesi anemia masih tinggi. Implementasi program WIFS terkendala dari berbagai faktor yaitu faktor politik, sosial, struktural dan pragmatis. Faktor perilaku merupakan faktor penting pada permasalahan ketidak patuhan kepatuhan remaja mengkonsumsi suplemen zat besi. Karena keterabatasan tenaga kesehatan, remaja putri tidak mendapatkan sosilisasi program WIFS secara lengkap sehingga pengetahuan, sikap dan kepatuhan dalam mengkonsumsi suplemen zat besi masih sangat rendah.

Solusi tepat dalam menyelesaikan permasalahan tersebut adalah menggunkan pendekatan peningkatan akses informasi (Qiang et al., 2012), pencegahan dengan pendekatan mheath karena saat ini smartphone merupakan komunikasi yang paling banyak digunakan di dunia(Vital Wave Consulting, 2009), intervensi mHealth dapat digunakan pada remaja untuk meningkatkan pengetahuan, sikap dan kepatuhan minum obat(Anderson et al., 2018), dengan adanya aplikasi kesehatan sebagai pendukung pengobatan dapat meningkatkan kepatuhan pengobatan (R.C. et al., 2017; Desilva et al., 2019) sehingga meningkatkan perubahan perilaku yang komprehensif dan dapat menyelesaikan hambatan pada lingkungan pasien (Curtis et al., 2019).

Aplikasi berbasis smartphone "Teenfit" sebagai suporting remaja putri pada program WIFS berdampak pada peningkatan pengetahuan dan sikap selanjutnya akan meningkatkan perilaku kepatuhan mengkonsumsi suplemen zat besi yang akan berefek peningkatan kadar hemoglobin pada remaja putri sekolah. Pembuatan aplikasi TeenFit menggunkan prinsip-prinsip komunikasi efektif ayng direkomendasikan oleh WHO yaitu dapat diakses, dapat ditindaklanjuti, relevan, tepat waktu, bisa dimengerti, kredibel dan terpercaya(World Health Organisation, 2017).

\section{METODE}

Penelitian ini dengan pendekatan kuantitatif cross secsional, dilakukan di Kabupaten Bantul, Indonesia pada remaja putri sekolah yang berusia 15-18 tahun. Pengumpulan data dilakukan dengan persetujuan responden dan dilakukan setelah mendapatkan keputusan layak etik dari komisi etik penelitian No.045/UN27.06.6.1/KEPK.EC/2020. Semua peserta harus melengkapi persetujuan sebelum meluli penelitian.

Variabel yang akan diteliti pada penelitian ini adalah sikap dan kepatuhan remaja tentang anemia serta kadar hemoglobin pada remaja sekolah. Pengumpuan data dilakukan dengan memberikan koesioner terkait sikap dan perilaku kepatuhan minum suplemen zat besi. Perilaku dan sikap remaja dapat diukur menggunkan koesioner yang telah dilakukan uji validitas dan reliabiltas. Sedangkan kadar hemoglobin menggunkan Alat tes hemoglobin digital.

\section{HASIL DAN PEMBAHASAN}

\section{Karakteristik Responden}

Karakteristik responden penelitian berdasarkan umur, sikap, eprilaku kepatuhan dan kadar hemoglobin disajikan pada tabel berikut : Tabel 1. Karakteristik Responden

\begin{tabular}{llcc}
\hline \multirow{2}{*}{ Karakteristik } & \multicolumn{1}{c}{ Kriteria } & Frekuensi & Presentase \\
\cline { 3 - 4 } & Usia & $\mathrm{n}$ & $\%$ \\
& $\begin{array}{l}\text { Remaja awal } \\
\text { (15-16 Tahun) }\end{array}$ & 152 & 63.6 \\
& $\begin{array}{l}\text { Remaja Akhir } \\
\text { (17 -18 Tahun) }\end{array}$ & 87 & 36.4 \\
Sikap & Baik & 143 & \\
& Kurang & 96 & 59.9 \\
Kepatuhan & Baik & 133 & 40,2 \\
& Kurang & 106 & 55.5 \\
N=239 & & & 44.7 \\
\hline
\end{tabular}

Sumber: Data penelitian (2020)

Hasil penelitian dari tabel 1 diketahui jumlah responden 239 remaja putri sekolah berusia 15 sampai 18 tahun, usia terbanyak pada kelompok kontrol yaitu usia remaja awal 15-16 Tahun tahunsebantyak 152 remaja putri (63.6\%). Sedangkan remaja putri yang memiliki dan remaja akhir dengan jumlah 87 (36.4\%). Remja putri yang memilki sikap baik 143 responden $(59.9 \%)$ dan sikap kurang sebanyak $96(40.2 \%)$ dan yang memiliki kepetuhan baik sebanyak 133 (55.5 \%), sedangkan yang memilki pengetahuan kurang sebanyak $106(44.7 \%)$

2. Sikap dan Perilaku Kepatuhan dengan Kadar Hemoglobin

Hasil penelitian hubungan sikap dan perilaku kepatuhan deangan kadar hemoglobin dapat dilihat pada tabel berikut:

Tabel 2. Distribusi Kategori menurut Karakteristik

\begin{tabular}{|c|c|c|c|c|c|c|c|}
\hline \multirow{3}{*}{ Kreteria } & \multicolumn{4}{|c|}{ Kadar hemoglobin } & & & \multirow{3}{*}{$\begin{array}{c}p \\
\text { value }\end{array}$} \\
\hline & \multicolumn{2}{|c|}{ Anemia } & \multicolumn{2}{|c|}{$\begin{array}{c}\text { Tidak } \\
\text { Anemia }\end{array}$} & \multicolumn{2}{|c|}{ Total } & \\
\hline & $\mathrm{N}$ & $\%$ & $\mathrm{n}$ & $\%$ & $\mathrm{~N}$ & $\%$ & \\
\hline \multicolumn{8}{|l|}{ Sikap } \\
\hline Baik & 51 & 35.7 & 92 & 64.3 & 143 & 100 & 0.014 \\
\hline Kurang & 54 & 56.3 & 42 & 43.7 & 96 & 100 & \\
\hline Kepatuhan & & & & & & & \\
\hline Baik & 47 & 35.4 & 86 & 64.6 & 133 & 100 & 0.01 \\
\hline Kurang & 79 & 74.5 & 27 & 25.5 & 106 & 100 & \\
\hline
\end{tabular}

Sumber: Data penelitian (2020)

Berdasarkan hasil penelitian yang ditunjukkan oleh tabel 2 didapatkan ada hubungan sikap dengan anemia remaja putri ( $p$ value 0,014). 
Namun dilihat berdasarkan kepatuhan minum TTD atau zat besi ada hubungan pengetahuan TTD dengan anemia remaja putri (pvalue 0,001 ). Analisis data berdasarkan uji chi square, dipilih variable yang memenuhi $\mathrm{p}<0,25$ untuk diuji lanjut dengan regresi logistik berganda. Adapun variabel itu adalah sikap, kepatuhan minum suplemen zat besi atau TTD berdasarkan uji chi square, lanjut dengan regresi logistik berganda.

\section{Sikap, perilaku kepatuhan dan Kadar Hemoglobin}

Hasil analisis multivariat anatara sikap, perilaku kepatuhan dan kadar hemoglobin dapat dilihat pada tabel berikut:

Tabel 3. Analisis Multivaiat

\begin{tabular}{lcccc}
\hline $\begin{array}{c}\text { Variable } \\
\text { independen }\end{array}$ & $\begin{array}{c}P- \\
\text { value }\end{array}$ & OR & \multicolumn{2}{c}{95 CI } \\
\hline Sikap & 0,001 & 3,300 & 1,641 & 6,636 \\
Kepatuhan & 0,014 & 2,048 & 1,040 & 4,035 \\
\hline
\end{tabular}

Berdasarkan hasil penelitian yang ditunjukkan pada tabel 3, model multivariat didapatkan bahwa perilaku kepatuhan minum suplemen zat besi merupakan faktor dominan terhadap kejadian anemia pada remaja putri. Remaja putri yang memiliki perilaku kepatuhan yang kurang akan berisiko 3,3 kali dibandingkan yang yang berperilku baik.

Permasalahan anemia remaja berdasarkan studi pendahuluan dan beberapa penelitian terdahulu bahwa permasalahan utama dalam program pemberian suplemen zat besi adalah ketidakpatuhan dalam mengkomsumsi suplemen zat besi. Hal ini disebabkan karena perilaku yang tidak mendukung terhadap program pencegahan anemia dikarena pengetahuan remaja masih rendah, sikap mereka masih belum mendukung. Sehingga dengan perilaku yang mendukung dan sikap yang baik dalam mengkonsumsi zat besi dapat meningkatkan kadar hemoglobin. Pemberian dukungan pada remaja dalam mengonsumsi tablet tambah darah secara rutin dapat memberikan dukungan terhadap program WIFS.

Hasil Analisis pada penelitian ini adalah adanya hubungan sikap dan kepatuhan pada remaja putri sekolah dengan kadar hemoglobin. Penelitian sebelumnya tentang perubahan perilaku yang dilakukan di India bahwa pemberian konseling akan meningkatakan pengetahuan remaja. Perubahan pengetahuan, perilaku pada penelitian di India menunjukan pendidikan dan konseling yang tepat dapat menghasilkan tingkat pengurangan anemia yang lebih baik dari pada pemberian suplemen saja.(Lakshmi, Easwaran and Saraswathy, 2016). Pengurangan Anemia melalui Inovasi Normatif atas dasar pemikiran bahwa pendekatan yang lebih komprehensif untuk pengurangan anemia diperlukan untuk menjangkau wanita di berbagai tingkatan (Sedlander et al., 2018).

Berdasarkan penelitian terdahulu hambatan pada program WIFS adalah kepatuhan remaja mengkonsumsi suplemen zat besi. Solusi untuk meningkatkan kepatuhan menggunkan beberapa pendekatan yang bertujuan untuk meningkatkan pengetahuan, sikap, sehingga diharapkan adanya perubahan perilaku kepatuhan dapat lebih optimal dan menghasilkan kualitas hidup yang lebih baik (Alberts et al., 2020).

Meningkatkan partisipasi aktif pasien melalui keaktifan dan pemberdayaan pasien tersebut terhadap dengan bukti semua peserta menunjukkan peningkatan kepatuhan, pengetahuan dan sikap (Anderson et al., 2018). Bukti lainya dapat dilihat pada penelitian menggunakan skrining anemia memudahkan untuk melakukan skrining anemia secara mandiri (Mannino et al., 2018). Pada kelompok remaja yang diberikan bebeapa pendekatan baik dengan penyuluhan langsung maupun pendidikan kesehatan berbasis individu dapat meningkatkan pengetahuan, sikap dan kepatuhan dalam meningkatkan kesehatan akan meningkatkan kadar hemoglobin.

Hal ini sejalan dengan penelitian berbasis web meningkatkan pengetahuan tentang talasemia dan sikap terhadap tindakan pencegahan di Malaysia (Ngim et al., 2019). Penelitian ini juga didukung oleh penelitian menggunakan pendekatan Intervensi dapat meningkatkan pengetahuan tentang penyakit menjadi lebih baik, serta meningkatkan kepatuhan terhadap dalam minum obat (Badawy et al., 2019).

Intervensi peningkatan pendidikan kesehatan juga dilakukan pada penelitian mengembangkan program pembelajaran tentang anemia terhadap pengetahuan dan sikap siswa sekolah menengah terhadap anemia di wilayah Jazan, Arab Saudi, hasil penelitan menunjukkan peningkatan yang signifikan dalam skor pengetahuan. Tidak ada perbedaan yang signifikan antara respon sikap sebelum dan sesudah intervensi pendidikan kesehatan. (Kotb et al., 2019).

Berdasarkan teori Green \& Kreuter, 1990 bahwa promosi kesehatan adalah segala bentuk kombinasi pendidikan kesehatan dan intervensi yang dirancang untuk memudahkan perubahan perilaku dan lingkungan yang kondusif bagi kesehatan (Green and Kreuter, 1990). Sikap dan perilaku minum tablet tambah darah yang baik dan rutin akan meningkatkan kadar hemoglobin, sehingga berdampak pada peningkatan kualiatas kesehatan khususnya peningkatan kadar hemoglobin. 
Dalam meningkatkan pengetahuan dan sikap serta perilaku minum tablet tambah darah, guru sebagai pembimbig, orang tua sebagai pendamping dan tenaga kesehatan dalam memberikan konseling dan pendampingan. Seperti pada penelitian di India tentang peran guru dan orang tua dalam mendampingi remaja pada program WIFS (Sethi et al., 2017), jumlah petugas kesehatan yang tidak memadai adalah tantangan utama yang dihadapi sektor kesehatan di negara berkembang. Bebrapa media dapat membantu dalam peningkatan pengetahuan dan informasi kepada pasien (Manganello et al., 2017).

Media sosial dapat dengan mudah diakses dan menarik bagi remaja serta memberi bantuan membuat pilihan berdasarkan informasi yang diharapkan (Lefevre et al., 2017). Permasalahan kekurangan petugas layanan kesehatan teknologi seluler dapat memberian sarana sebagai dukungan yang mereka butuhkan untuk menjalankan fungsi mereka secara efektif dan mandiri (OECD-Harvard Global Health Institute, 2017) (Thinley, Namgyal and Id, 2019). Peningkatan kepatuhan dalam mengkonsumsi suplemen zat besi setiap minggu satu tablet pada remaja puti dapat meningkatkan kadar hemoglobin dan menurunkan prevalesi anemia.

Sejalan dengan teori tindakan yang direncanakan (Theory of planned behavior) adalah teori yang menjelaskan perilaku manusia, menghubungkan keyakinan dan perilaku. Teori TPB (Theory of planned behavior) direalisasikan untuk menghubungkan antara keyakinan, sikap dan niat perilaku (Ajzen, 2005). Perubahan perilaku kesehatan dapat dilakukan dengan pendekatan komunikasi melalui promosi kesehatan. tarategi pendekatan dengan mengikuti perkembangan zaman era digital dapat menggunakan media yang dengan mudah diterima dengan mudah oleh remaja putri sekolah karena smatrphone merupakan media yang sudah familier dengan keberadaan remaja. Sehingga strategi ini dapat memberikan dampak perubahan pengetahuan selanjutnya perubahan sikap dan perubahan perilaku.

Remaja memlliki sikap yang positif terhadap program WIFS. Dengan demikian diharapkan dapat berpartisipasi aktif untuk mengkonsumsi zat besi secara teratur. Kepatuhan dalam mengkonsumsi suplemen zat besi telah dilakukan banyak pendekatan pengembangan komunikasi pendidikan pada remaja dengan memanfaatkan teknologi dengan mengintegrasikan beberapa aspek yaitu aspek perilaku mulai dari pengetahuan, sikap dan kepatuhan dengan pemberian pendidikan dan pengingat untuk minum suplemen zat besi.
Berdasarkan temuan-temuan tersebut pendekatan menggunakan pendidikan kesehatan merupakan upaya untuk memberikan pelayanan kesehatan kepada remaja dalam mencegah anemia, solusi dalam menangani hambatan kurangnya pengetahuan, sikap dan kepatuhan untuk minum TTD setiap minggu satu tablet. Promosi kesehatan merupakan upaya dalam memberdayakan individu dengan meningkatkan pengetahuan, sikap dan perilaku kepatuhan minum suplemen zat besi. Permasalahan pengetahuan, sikap dan perilaku yang masih kurang penanganan hal ini menjadi kendala utama. Dengan memberikan pendidikan kesehatan pada remaja dapat menjadi solusi dalam permasalahan ini namun kekurangan petugas layanan kesehatan adalah tantangan utama yang dihadapi sektor kesehatan negara berkembang. Berbagai media dapat membantu dalam peningkatan pengetahuan dan informasi kepada pasien sebagai dukungan yang mereka butuhkan untuk menjalankan fungsi mereka secara efektif dan mandiri.

\section{KESIMPULAN DAN REKOMENDASI}

Berdasarkan penelitian tersebut sikap dan kepatuhan minum suplemen zat besi akan berpengaruh terhadap kadar hemoglobin pada remaja putri. Upaya untuk meningkatkan sikap dan perilaku minum suplemen zat besi perlu ditingkatakan untuk meningkatkan keteraturan remaja dalam mengkonsumsi suplemen zat besi atau tablet tambah darah.

\section{REFERENSI}

Ajzen, I. (2005) 'Theory ajzeni-2005-attitudespersonality-and-behaviour-2nd-ed-openuniversity-press.pdf'. New York: Open University Press.

Alberts, N. M. et al. (2020) 'Development of the InCharge Health Mobile App to Improve Adherence to Hydroxyurea in Patients With Sickle Cell Disease: User-Centered Design Approach Corresponding Author':, 8(7). doi: $10.2196 / 14884$.

Alizadeh, L. et al. (2014) 'Impact of Maternal Hemoglobin Concentration on Fetal Outcomes in Adolescent Pregnant Women', Iranian Red Crescent Medical Journal, 16(8), pp. 1-5. doi: 10.5812/ircmj. 19670.

Anderson, L. M. et al. (2018) 'Mobile health intervention for youth with sickle cell disease: Impact on adherence, disease knowledge, and quality of life', Pediatric Blood and Cancer, 65(8), pp. 19. doi: 10.1002/pbc. 27081 .

Azupogo, F. et al. (2019) 'Agro-ecological zone and 
farm diversity are factors associated with haemoglobin and anaemia among rural schoolaged children and adolescents in Ghana', Maternal and Child Nutrition, 15(1), pp. 1-11. doi: $10.1111 / \mathrm{mcn} .12643$.

Badawy, S. M. et al. (2019) 'Computer and mobile technology interventions to promote medication adherence and disease management in people with thalassemia', Cochrane Database of Systematic Reviews, 2019(6). doi: 10.1002/14651858.CD012900.pub2.

Compaoré, A. et al. (2018) 'Community approval required for periconceptional adolescent adherence to weekly iron and/or folic acid supplementation: A qualitative study in rural Burkina Faso', Reproductive Health, 15(1), pp. 1-8. doi: 10.1186/s12978-018-0490-y.

Curtis, K. et al. (2019) 'A medication adherence app for children with sickle cell disease: Qualitative study', JMIR mHealth and uHealth, 7(6), pp. 119. doi: 10.2196/mhealth.8130.

Desilva, M. et al. (2019) 'The Supporting Adolescent Adherence in Vietnam ( SAAV) study: study protocol for a randomized controlled trial assessing an mHealth approach to improving adherence for adolescents living with HIV in Vietnam', pp. 1-13.

Fentie, K., Wakayo, T. and Gizaw, G. (2020) 'Prevalence of Anemia and Associated Factors among Secondary School Adolescent Girls in Jimma Town, Oromia Regional State, Southwest Ethiopia', Anemia, 2020. doi: $10.1155 / 2020 / 5043646$.

Gebreyesus, S. H. et al. (2019) 'Anaemia among adolescent girls in three districts in Ethiopia', BMC Public Health, 19(1), pp. 1-11. doi: 10.1186/s12889-019-6422-0.

Global, W. H. A. and Targets, N. (2012) 'Box 1: What is anaemia?', pp. 1-7. doi: WHO/NMH/NHD/14.3.

Green, L. W. and Kreuter, M. W. (1990) 'HEALTH PROMOTION AS A PUBLIC’, pp. 319-334.

Habib, N., Abbasi, S. U. R. S. and Aziz, W. (2020) 'An Analysis of Societal Determinant of Anemia among Adolescent Girls in Azad Jammu and Kashmir, Pakistan', Anemia, 2020. doi: $10.1155 / 2020 / 1628357$.

Kotb, M. M. et al. (2019) 'Effect of Health Education Programme on the Knowledge of and Attitude about Sickle Cell Anaemia among Male Secondary School Students in the Jazan Region of Saudi Arabia: Health Policy Implications', BioMed Research International, 2019. doi: 10.1155/2019/9653092.

Kounnavong, S. et al. (2020) 'Anaemia among adolescents: assessing a public health concern in Lao PDR', Global Health Action, 13(sup2). doi: 10.1080/16549716.2020.1786997.

Koura, Ghislain K. et al. (2012) 'Anaemia during pregnancy: Impact on birth outcome and infant haemoglobin level during the first 18 months of life', Tropical Medicine and International Health, 17(3), pp. 283-291. doi: 10.1111/j.1365-3156.2011.02932.x.

Koura, Ghislain K et al. (2012) 'Anaemia during pregnancy: Impact on birth outcome and infant haemoglobin level during the first 18 months of life', Tropical Medicine and International Health, 17(3), pp. 283-291. doi: 10.1111/j.1365-3156.2011.02932.x.

Lakshmi, E., Easwaran, P. and Saraswathy, E. (2016) 'An intervention study to combat iron deficiency anaemia in adolescent girls - Food fortification strategy', Biosciences Biotechnology Research Asia, 13(2), pp. 11411146. doi: $10.13005 / \mathrm{bbra} / 2144$.

Learnt, L. et al. (2018) 'Weekly iron and folic acid supplementation as an anaemia-prevention strategy in women and adolescent girls', Who, p. 40 .

Lefevre, A. E. et al. (2017) 'Mobile Technology for Community Health in Ghana: What happens when technical functionality threatens the effectiveness of digital health programs?', BMC Medical Informatics and Decision Making, 17(1), pp. 1-17. doi: 10.1186/s12911017-0421-9.

Manganello, J. et al. (2017) 'The relationship of health literacy with use of digital technology for health information: Implications for public health practice', Journal of Public Health Management and Practice, 23(4), pp. 380-387. doi: 10.1097/PHH.0000000000000366.

Mannino, R. G. et al. (2018) 'Smartphone app for noninvasive detection of anemia using only patientsourced photos', Nature Communications, 9(1), pp. 2-11. doi: 10.1038/s41467-018-07262-2.

Mengistu, G., Azage, M. and Gutema, H. (2019) 'Iron Deficiency Anemia among In-School 
Adolescent Girls in Rural Area of Bahir Dar City Administration, North West Ethiopia', Anemia, 2019, pp. 1-8. doi: $10.1155 / 2019 / 1097547$.

Ngim, C. F. et al. (2019) 'A web-based educational intervention module to improve knowledge and attitudes towards thalassaemia prevention in Malaysian young adults', Medical Journal of Malaysia, 74(3), pp. 219-225.

OECD-Harvard Global Health Institute (2017) " Mobile Technology -Based Services For Global Health And Wellness : Opportunities And Challenges " Summary of Main points from the OECDHARVARD Global Health Institute Expert Consultation of 5-6', (October 2016).

Organization, W. H. (2017) 'WHO Recommendations on Adolescent Health', (August), p. 28.

Qiang, C. Z. et al. (2012) 'Mobile Applications for the Health Sector', (April).

R.C., K. et al. (2017) 'mhealth intervention to support asthma self-management in adolescents: The adapt study', Patient Preference and Adherence, 11, pp. 571-577. Available at: https://www.dovepress.com/getfile.php?fileID $=35518 \% 5 \mathrm{Cnhttp}: / /$ ovidsp.ovid.com/ovidweb. cgi? $\mathrm{T}=\mathrm{JS} \& \mathrm{PAGE}=$ reference $\& \mathrm{D}=\mathrm{emed} 18 \mathrm{~b} \& \mathrm{~N}$ EWS $=N \& A N=614915771$.

Sataloff, R. T., Johns, M. M. and Kost, K. M. (no date) No 主観的健康感を中心とした在宅高齢者 における 健康関連指標に関する共分散構 造分析Title.

Sedlander, E. et al. (2018) 'Designing a socio-normative intervention to reduce anemia in Odisha India: A formative research protocol', Gates Open Research, 2(May), p. 15. doi: 10.12688/gatesopenres.12808.1.

Sedlander, E. et al. (2020) 'Moving beyond individual barriers and identifying multi-level strategies to reduce anemia in Odisha India', BMC Public Health, 20(1), pp. 1-16. doi: 10.1186/s12889020-08574-z.

Sethi, V. et al. (2017) 'Applying Positive Deviance for Improving Compliance to Adolescent Anemia Control Program in Tribal Communities of India', Food and Nutrition Bulletin, 38(3), pp. 447-452. doi: 10.1177/0379572117712791.

Thinley, S., Namgyal, K. and Id, A. M. (2019) 'Social media and control of soil-transmitted helminthiasis in Bhutan', (September 2018), pp.
2018-2020.

Vital Wave Consulting (2009) mHealth for Development.

WHO (2017) Nutritional Anaemias : Tools for Effective Prevention, World Health Organization.

World Health Organisation (2017) 'WHO Strategic Communications Framework', World Health Organization, 2017(July), p. 56.

World Health Organization (2011) 'Prevention of iron deficiency anaemia in adolescents', Searo, p. 50. doi: 10.1109/VTC.1982.1623054. 